\title{
Estimation of the Environmental Impact for Recycling Blast Furnace Slag with a Hydrothermal Reaction Based on Life Cycle Inventory Data
}

\author{
Soon-Jae TAE, ${ }^{1 * *}$ Tsuyoshi ADACHI $^{2)}$ and Kazuki MORITA ${ }^{3)}$ \\ 1) Formerly a Graduate Student at the Institute of Industrial Science, The University of Tokyo. Now at Steelmaking Technology \\ Development Team, R\&D Center of Hyundai Steel Corporation, Dangjin-shi, 167-32 Republic of Korea. \\ 2) Department of International Resource Sciences, Akita University, Akita-shi, 010-8502 Japan. \\ 3) Department of Material Engineering, The University of Tokyo, Tokyo, 113-8656 Japan.
}

(Received on June 9, 2016; accepted on September 26, 2016; J-STAGE Advance published date: November 18, 2016)

\begin{abstract}
Blast furnace (BF) slag has been recycled in the construction industry mainly as cement and concrete. However, in the past few years, recycling conditions have changed and other recycled materials have become dominant; thus, new applications for BF slag need to be considered. In this study, we first reviewed applications in which $\mathrm{BF}$ slag was treated by hydrothermal reactions. Under hydrothermal conditions, tobermorite $\left(\mathrm{Ca}_{5} \mathrm{Si}_{6} \mathrm{O}_{16}(\mathrm{OH})_{2} \cdot 4 \mathrm{H}_{2} \mathrm{O}\right)$ was formed from $\mathrm{BF}$ slag. This tobermorite, which was produced in a $\mathrm{CaO}-\mathrm{SiO}_{2}-\mathrm{H}_{2} \mathrm{O}$ system, was used as the main binding mineral in autoclaved lightweight concrete $(\mathrm{ALC})$, and the corresponding ALC exhibited excellent properties in terms of heat insulation and lightness.

Next, in the present study, the utilization of BF slag in the ALC manufacturing process as an alternative raw material was evaluated based on the environmental impacts associated with its use. Specifically, the environmental impact was evaluated with life cycle inventory $(\mathrm{LCl})$ data for the resulting $\mathrm{CO}_{2}$ emissions. The LCl data for ALC prepared with BF slag were compared with LCA data for other conventional production processes, and the results showed that the ALC prepared with recycled BF slag had lower levels of $\mathrm{CO}_{2}$ emissions than the other processes that were evaluated.
\end{abstract}

KEY WORDS: blast furnace slag; hydrothermal treatment; recycling; life cycle inventory.

\section{Introduction}

Blast furnace (BF) slag has been widely recycled by civil engineering and construction industries. However, the amount of recycled BF slag has now reached the saturation point, and the development of new value-added products will be essential for promoting sustainable societies. ${ }^{1)}$

Recently, a hydrothermal reaction was proposed as a potential approach for solving this problem. ${ }^{2)}$ In general, hydrothermal processes are useful for the synthesis and solidification of materials from various raw materials or waste matter containing water, and the processes take place at low temperatures (below $300^{\circ} \mathrm{C}$ ) in the presence of saturated water vapor. ${ }^{3)}$ Several researchers including the authors have investigated the use of hydrothermal reactions to treat iron-steelmaking slag and glass. ${ }^{4)}$ In particular, we have investigated the reaction mechanism and the behavior of BF slag under various hydrothermal conditions and found that tobermorite $\left(\mathrm{Ca}_{5} \mathrm{Si}_{6} \mathrm{O}_{16}(\mathrm{OH})_{2} \cdot 4 \mathrm{H}_{2} \mathrm{O}\right)$ is formed from $\mathrm{BF}$ slag under hydrothermal conditions. ${ }^{5)}$ Tobermorite is the main binding mineral in autoclaved lightweight concrete

* Corresponding author: E-mail: sjsteel75@gmail.com

DOI: http://dx.doi.org/10.2355/isijinternational.ISIJINT-2016-358
(ALC), and this material is known to have excellent thermal and heat insulation properties. This means that hydrothermally treated BF slag can be effectively utilized in ALC.

Meanwhile, the authors and other researchers have reported that hydrothermal reactions play an important role in the immobilization of heavy metals. The reactions and products can be used for the synthesis and production of functional ceramics from pure substances or wastes. ${ }^{6-8)}$ They can also be used in the immobilization process for forming a hydrothermal phase and incorporating heavy metals into that phase. ${ }^{9,10)}$ As a result of further study, if a number of such products that incorporate iron and steelmaking slag can be commercialized, such as ALC, this would represent a significant contribution to the field of steel slag recycling.

The hydrothermal reactions involved with the production process take place below $300^{\circ} \mathrm{C}$, and this temperature can be attained easily by utilizing the abundant low-temperature heat sources in the iron and steelmaking processes. In a recent research report on integrated steel mill generated waste, $25 \%$ of the waste was recovered, and findings were presented for the energy usage and $\mathrm{CO}_{2}$ emissions associated with this recovery; efforts to increase the recovery rate further are in progress. ${ }^{11)}$ Hydrothermal reactions could result in the development of a new sustainable system loop for 
recycling the byproducts of iron and steelmaking processes.

The objective of this study was to investigate the utilization of BF slag in the ALC manufacturing process, and the slag was obtained from an integrated steel mill as a substitutive raw material. The environmental emissions of the use of BF slag in ALC was calculated based on life cycle inventory (LCI) data for $\mathrm{CO}_{2}$ emissions. In addition, the $\mathrm{CO}_{2}$ emissions for this study were compared with other conventional production processes.

\section{Analysis Method}

\subsection{The Scope Definition}

The LCI in this study is carried out based on the general LCA method, including the scope definition, inventory analysis, and impact assessment. ${ }^{12)}$ The first step is to clearly define the scope; which has been done in this section. The compositions of ALC and BF slag are shown in Table $\mathbf{1 .}$ The general production process for ALC is shown in Fig. 1. The ALC product contains lime $(\mathrm{CaO})$ and silica $\left(\mathrm{SiO}_{2}\right)$ as the main raw materials, and product is obtained by heattreating the main raw materials in water.

Table 1. Chemical composition and structure of ALC compared with the BF slag.

\begin{tabular}{ccccccccc}
\hline \multirow{2}{*}{ Material } & \multicolumn{9}{c}{ Average content (mass\%) } & Structure \\
\cline { 2 - 5 } & $\mathrm{SiO}_{2}$ & $\mathrm{CaO}$ & $\mathrm{Al}$ & $\mathrm{Al}_{2} \mathrm{O}_{3}$ & Cement & Other & \\
\hline ALC & $60-70$ & $10-20$ & $0.05-0.1$ & - & $15-30$ & $2-5$ & $\begin{array}{c}\text { Tobermorite } \\
\mathrm{C}-\mathrm{S}-\mathrm{H}^{\mathrm{a}}\end{array}$ \\
BF slag & $30-40$ & $35-50$ & - & $10-20$ & - & $\sim 10$ & Amorphous $^{\mathrm{b}}$ \\
\hline
\end{tabular}

${ }^{\mathrm{a}} \mathrm{C}(\mathrm{CaO}), \mathrm{S}\left(\mathrm{SiO}_{2}\right), \mathrm{H}\left(\mathrm{H}_{2} \mathrm{O}\right) ;{ }^{\mathrm{b}}$ water quenched slag

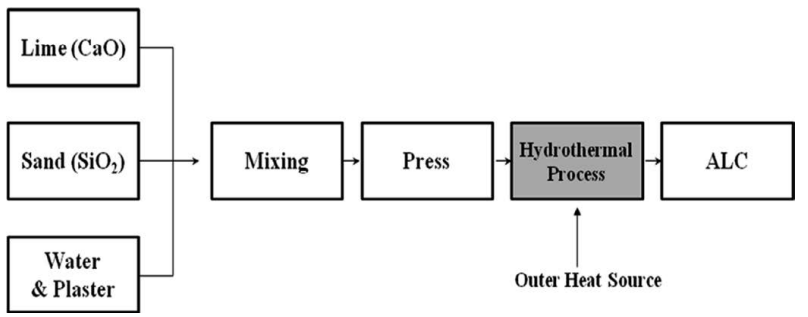

Fig. 1. The production process of autoclaved lightweight concrete.
The main structural component of ALC, as shown in Table 1 , is tobermorite; it is the same product that was studied during the authors' investigations of hydrothermal treatments for BF slag. ${ }^{5,13)}$ Given the above results, BF slag should be suitable as a raw material during the production of ALC.

The typical ALC is made from silica sand, lime, cement and water, to which an expanding plaster is added. The ALC manufacturing process, as shown in Fig. 1, starts when the sand is ground to the required fineness in a ball mill. Raw materials are then automatically weighed and measured in the mixer along with water. After mixing, the slurry is poured into metal molds and press, where the expanding agent reacts with the other elements. The final phase in the production process is hydrothermal treatments in autoclaves for up to 12 hours; an external heat source was required in conventional ALC manufacturing process.

However, if BF slag is utilized and a hydrothermal treatment plant can be installed in an integrated steel mill, the waste heat discarded from the integrated steel mill can be used as the heat source, and thus, it is possible to develop an efficient process.

To determine the current situation for recycled materials and to investigate the potential for reducing the environmental impacts by promoting recycling, it is necessary to establish a process flow for the objective materials. Here, the life cycle calculations were set up with the use of the following three assumptions:

(1) Use of BF slag as a raw material is $100 \%$;

(2) The production process is the same as the process used in conventional ALC production;

(3) The heat source for hydrothermal treatment is derived from the waste heat generated during the $\mathrm{BF}$ process, and the necessary production equipment is installed inside of an integrated steel mill.

\subsection{Life Cycle Inventory Analysis}

Figure 2 shows the life cycle flow of the ALC production process that uses BF slag along with hydrothermal reactions. The ALC production process shown here in the present study was modeled to investigate the environmental impact of ALC production using BF slag. Importantly, this is a virtual model in which a reference process and BF slag have been

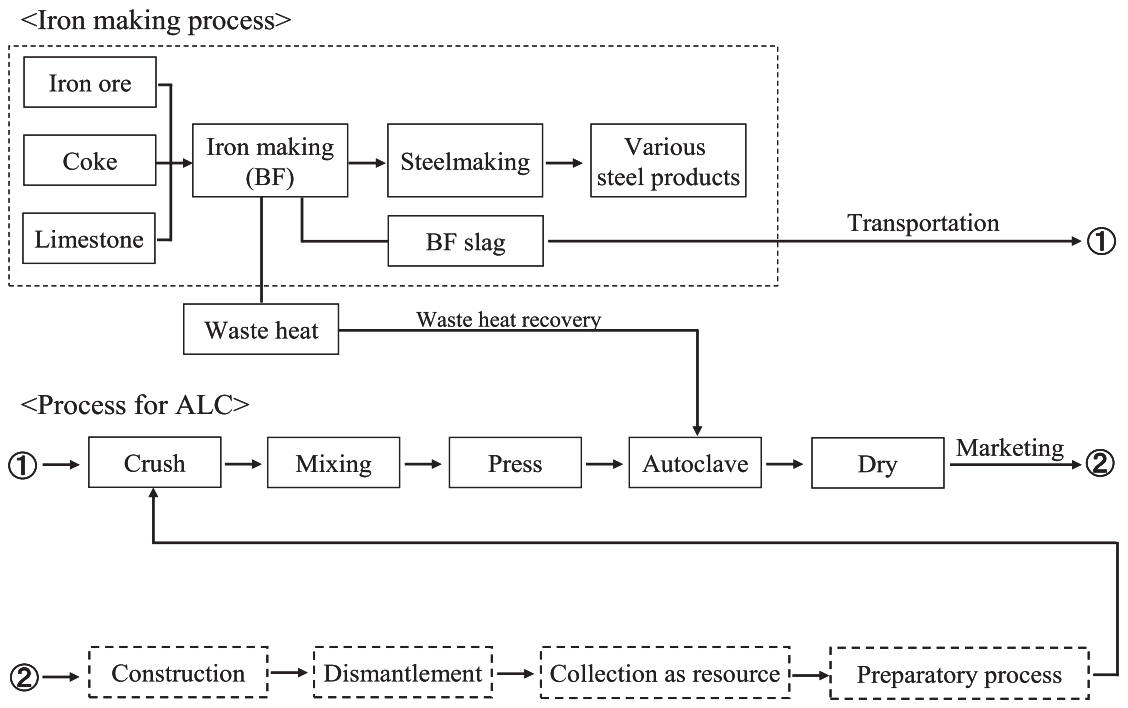

Fig. 2. Life cycle flow of ALC production in an integrated steel mill. 
used, and the potential negative environmental impacts associated with the generation of the BF slag (process involving pig iron) were not considered here because they were outside of the system boundary. The BF slag was simply considered as a raw material in the ALC production process.

The system is described in detail as follows. In the BF, the iron ore is melted with coke and limestone at a high temperature, and pig iron is reduced by coke. In this case, the components other than the iron of the iron ore are separated and recovered along with the ash content of limestone and coke, i.e., this becomes $\mathrm{BF}$ slag. It was produced at a rate of about $290 \mathrm{~kg}$ per one ton of pig iron. ${ }^{14}$ )

The life cycle of ALC production with BF slag as a raw material is depicted in Fig. 2, and the cycle starts when "(1) BF slag" is produced. Produced "(1) BF slag" is then moved to the ALC production plant where it is crushed and mixed with water; next, the material is processed into a panel shape by a press and this becomes the work pieces (i.e., product in a semi-cured state).

The semi-finished products are then hydrothermally treated at high temperatures and high pressures in an autoclave, and the final product is shaped to a predetermined size by machining operations. The temperature in the autoclave was about $250^{\circ} \mathrm{C}$, and the heat source was supplied by waste heat from the pig iron process.

After use, the waste ALC materials is possible to reuse or recycling as shown in "(2)" in Fig. 2. Once their service life is over, the ALC waste is reused for purposes such as waterproofing. Waterproofing of materials is typically performed during building construction, and after separating the interior and exterior finishing materials, the interior of the reinforcement was removed and recycled as a raw material for ALC production. In addition, in response to the environmental problems, the ALC association in Japan undertook several measures and collected and recycled almost $100 \%$ wasted ALC materials since 2008. So, this system is almost closed and circulated. Also, disposal issues for reasons such as old building dismantlement were also considered. The ACL waste generated at demolition sites can be disposed of easily since it does not contain hazardous substances.

\section{Results and Discussion}

\subsection{Evaluation of Environmental Emissions}

In the present study, the negative environmental impact resulting from raw material use during material manufacturing was quantified based on the production of $1 \mathrm{t}$ of ALC material that was produced with BF slag.

Currently, BF slag has been discharged about 2500000 t/year averagely from last five year's data and $98 \%$ of them have been already recycled well in civil engineering and construction materials. For amount of BF slag for a raw material ALC proposed in this study is too small. The productive capacity in a day of ALC is 2500 ton/day and the actual average production over the last decade up to 120000 tons at least 40000 tons. $^{15}$ ) This amount is less than $0.5 \%$ in relation to the BF slag recycled field, so raw material of ALC by BF slag does not adversely affect to the current BF slag market. However, the amount of recycled BF slag has now reached the saturation point, and the development of new value-added products will be essential for promoting sustainable societies and BF slag used to the ALC materials utilization is expected to be very efficient.

The main processing inputs were assumed to be as follows.

The electric power used for the disintegrator, blending machine, machine press, and dryer was calculated according to the grinding operations for the BF slag. When ALC materials were produced in units of $1 \mathrm{t}$, a certain amount of BF slag and water were required, and these amounts were assumed to be about $860 \mathrm{~kg}$ and $250 \mathrm{~kg}$, respectively. The external energy use was assumed to be zero given that the fuel for the heat treatments was composed of waste heat from the steel manufacturing process, and the temperature of the water used in the heat treatments was set to $250^{\circ} \mathrm{C}$; the water was assumed to have been heated to this temperature from room temperature. ${ }^{16)}$

The prediction of the amount of energy consumption for the ALC production process was about $23.55 \mathrm{KJ} / \mathrm{t}$, while the exhaust energy for when the pig iron $(1 \mathrm{t})$ was produced was about $11.14 \mathrm{GJ} / \mathrm{t}$, according to values published in the literature, ${ }^{17-19)}$ these values represent adequate amounts for the application of the waste heat. Table 2 shows the input requirements for the $\mathrm{BF}$ slag, other raw materials, and fuel used during the ALC production process; these values were determined according to the above mentioned assumptions.

The $\mathrm{CO}_{2}$ emissions from the production process were considered as a negative environmental impact in the present study because $\mathrm{CO}_{2}$ is a heat-trapping gas that contributes to climate change. Various LCI data from the LCA database of the LCA Japanese Forum, which have high reliability, were used to calculate the emission levels for this section. ${ }^{19}$ Data on steel slag disclosed by industries and the Ministry of the Environment were collected and the inventory was analyzed. Moreover, a previous LCI evaluation that was conducted by an ALC producing company was used as comparison data. ${ }^{16)}$ The $\mathrm{CO}_{2}$ emission factors for the raw fuel and production processes that were used in the calculations of $\mathrm{CO}_{2}$ emissions are shown in Table 3.

Table 4 shows the results for the $\mathrm{CO}_{2}$ emissions. The LCI analysis results for conventionally produced ALC material that uses $\mathrm{CaO}$ and $\mathrm{SiO}_{2}$ powder are also shown for comparative purposes. ${ }^{16)}$

Table 2. Autoclaved lightweight concrete manufacturing requirements for materials and fuel.

\begin{tabular}{cccc}
\hline \multicolumn{2}{c}{ Function } & Functional value & Units \\
\hline Raw material & $\begin{array}{c}\text { Blast furnace } \\
\text { slag }\end{array}$ & 860 & $\mathrm{~kg} / \mathrm{t}$-ALC \\
Additions & Water & 250 & \\
Fuel & $\begin{array}{c}\text { Waste heating } \\
\text { source } \\
\text { Electric power }\end{array}$ & 0.024 & $\mathrm{GJ} / \mathrm{t}$-ALC \\
\hline
\end{tabular}

Table 3. $\mathrm{CO}_{2}$ emission factors for each fuel.

\begin{tabular}{cccc}
\hline \multicolumn{2}{c}{ Impact category } & $\begin{array}{c}\text { Global warming } \\
\text { potential }\end{array}$ & Unit \\
\hline Raw material & Slag powder & 24.1 & $\mathrm{~kg}-\mathrm{CO}_{2} / \mathrm{t}$ \\
Processes & Electric power & 0.369 & $\mathrm{~kg} / \mathrm{kwh}$ \\
& Steam & 0.057 & $\mathrm{tCO}_{2} / \mathrm{GJ}$ \\
\hline
\end{tabular}


The $\mathrm{CO}_{2}$ emissions decreased from $356 \mathrm{~kg}-\mathrm{CO}_{2} / \mathrm{t}$ for the conventional process to $15.5 \mathrm{~kg}-\mathrm{CO}_{2} / \mathrm{t}$ for the process in which ALC material was produced with BF slag as the raw material in an integrated steel mill system; these large reductions were made possible by the use of waste heat and recycled slag from the iron making. The effect on $\mathrm{CO}_{2}$ reductions from using the $\mathrm{BF}$ slag as a $\mathrm{CaO}-\mathrm{SiO}_{2}$ powder was extremely high. In particular, when slag is the byproduct of the $\mathrm{BF}$, we can disregard $\mathrm{CO}_{2}$ emissions from the raw material production process; the amount of $\mathrm{CO}_{2}$ generated during the manufacturing processes for silica and lime was included in the calculations for the conventional process.

\subsection{Environmental Credit Based on the $\mathrm{CO}_{2}$ Results}

We compared the LCI results for the ALC material made from the use of BF slag with results for pure materials such as Portland cement. Table 5 and Fig. $\mathbf{3}$ show the inputs and the $\mathrm{CO}_{2}$ emissions per ton of product for all of these products. Recycling the $\mathrm{BF}$ slag contributed greatly to the decrease in the environmental impact, and this was an effective use of resources because $\mathrm{CO}_{2}$ emissions from the calcinations process for quicklime did not have to be accounted

Table 4. $\mathrm{CO}_{2}$ emission levels for each process.

\begin{tabular}{ccc}
\hline \multirow{2}{*}{ Process } & \multicolumn{2}{c}{$\mathrm{CO}_{2}$ emission level $(\mathrm{kg} / \mathrm{t}-\mathrm{ALC})$} \\
\cline { 2 - 3 } & Conventional & $\mathrm{BF}$ slag \\
\hline Raw materials & & 24.1 \\
Pressing & 356 & 14.1 \\
$\begin{array}{c}\text { Hydrothermal } \\
\text { treatment }\end{array}$ & & 1.4 \\
\hline Total & 356 & 15.5 \\
\hline
\end{tabular}

Table 5. Inputs and $\mathrm{CO}_{2}$ emissions per ton of the production material (unit: $\mathrm{kg} / \mathrm{t}$ ).

\begin{tabular}{|c|c|c|c|c|c|}
\hline Inven & $\begin{array}{c}\text { Portland } \\
\text { cement }\end{array}$ & $\begin{array}{c}\mathrm{BF} \\
\text { cement (B) } \\
\text { (1) }\end{array}$ & $\begin{array}{c}\text { ALC } \\
\text { (BF slag) } \\
\text { (2) }\end{array}$ & $\begin{array}{c}\mathrm{CO}_{2} \\
\text { emissions } \\
\text { (1)-(2) }\end{array}$ & $\begin{array}{l}\text { Reduction } \\
\text { rate for } \\
\mathrm{CO}_{2} \%\end{array}$ \\
\hline Limestone & 472.5 & 272.1 & - & 271.1 & 100 \\
\hline Electric power & 311.1 & 190.4 & 15.5 & 174.9 & 91.9 \\
\hline Total & 783.6 & 462.5 & 15.5 & 447.0 & 96.6 \\
\hline
\end{tabular}

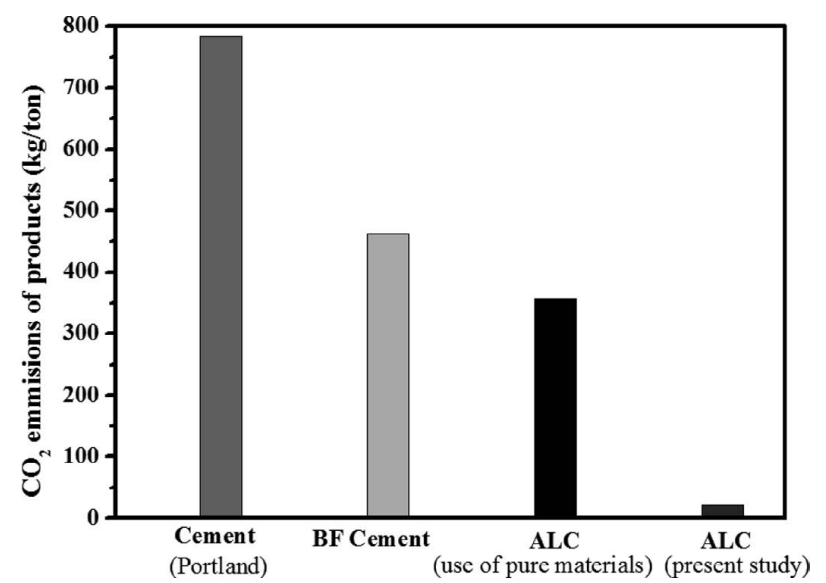

Fig. 3. Comparison of $\mathrm{CO}_{2}$ emission levels for different products with recycled $\mathrm{BF}$ slag. for in the inventory when the BF slag was used as the $\mathrm{Ca}$ source in the clinker manufacturing process.

The $\mathrm{CO}_{2}$ emission comparisons for the cases where $\mathrm{BF}$ cement and BF slag were used as ALC raw materials are shown in Table 5 and Fig. 3. As for making the ALC material, it was confirmed that the amount of the reduction of $\mathrm{CO}_{2}$ was $447.0 \mathrm{~kg} / \mathrm{t}$ from the production of $\mathrm{BF}$ cement as shown in Table 5. Thus, it may be possible to achieve a reduction of about $7000000 \mathrm{t}$ annually compared with the case that uses BF cement assuming that the whole quantity (16 $730000 \mathrm{t}$ ) used for BF slag production according to fiscal year 2014 in Japan was used as ALC material. ${ }^{17)}$

\section{Conclusions}

In the present study, we investigated the use of hydrothermal reactions to treat $\mathrm{BF}$ slag, and tobermorite was the main binding mineral formed. This treated BF slag was proposed to be a suitable new raw material for the ALC production process, as ALC produced with BF slag has been shown to have excellent heat insulation and lightness properties, which are ideal for building materials. In addition, metals such as hexavalent chromium can be immobilized during the hydrothermal treatments of BF slag, and this has several environmental benefits. The utilization of BF slag in the ALC manufacturing process as an alternative raw material was evaluated according to the environmental impact, which was calculated based on LCI methodology and $\mathrm{CO}_{2}$ emissions. The findings showed that the production process for ALC material that uses BF slag was associated with a greatly decreased environmental impact compared to that of conventional production processes.

\section{Acknowledgement}

The authors would like to thank Professor T. Tanaka, Department of Materials Science and Processing, Osaka University, for the discussion and helpful advice on the hydrothermal reaction.

\section{REFERENCES}

1) M. Fujiwara: Tetsu-to-Hagané, 8 (2003), 883.

2) T. Tanaka, Y. Yamasaki, S. Hara, S. Katsuyama and K. Marukawa: CAMP-ISIJ, 16 (2003), 963, CD-ROM.

3) N. Yamazaki: J. Ceram. Soc. Jpn., 111 (2003), 709.

4) T. Tanaka, T. Yoshikawa and N. Hirai: Bull. Iron. Steel. Inst., 14 (2009), 353

5) S-J. Tae and K. Morita: ISIJ Int., 47 (2007), 1813.

6) S-J. Tae and K. Morita: ISIJ Int., 48 (2008), 1311.

7) K. Byrappa and M. Yoshimura: Handbook of Hydrothermal Technology, Noyes Publications, New York, (2001), 1.

8) J. Reinik, I. Heinmaa, J. P. Mikkola and U. Kirso: Fuel, 86 (2007), 669.

9) R. Inoue and H. Suito: ISIJ Int., 42 (2002), 930

10) T. Ida: CAMP-ISIJ, 19 (2006), 865.

11) T. Akiyama and J. Yagi: Tetsu-to-Hagané, 82 (1996), 177.

12) K. Halada: Ceramic, 11 (2002), 37.

13) J. Ha, T. Hashida and S. Teramura: J. Mater. Sci. Lett., 19 (2001), 1791.

14) T. Miyamoto, K. Torii, K. Akahane and S. Hayashiguchi: NSSMC Tech. Rep., 339 (2014), 102.

15) Ministry of Economy: The Trade and Industry of Japan, (2015), http://www.meti.go.jp, (accessed 2016-05-30).

16) YTONG Company: Report of Environmental Product Declaration, AUB, Konigswinter, (2005), 1.

17) Report of Production of Slag in Japan, ed. by Nippon Slag Association, (2015), http://www.slg.jp/statistics/report.html, (accessed 2016-06-01).

18) T. Akiyama and J. Yagi: Tetsu-to-Hagané, 82 (1996), 177.

19) The Japan Environmental Management Association: The LAC Data for Production, JEMAI, Tokyo, (2015), http://www.jemai.or.jp, (accessed 2016-06-02) 